University for Business and Technology in Kosovo

UBT Knowledge Center

UBT International Conference

2017 UBT International Conference

Oct 28th, 9:00 AM - 10:30 AM

\title{
Control some quality parameters of the natural juice of blueberry with different fruit content
}

\author{
Namik Durmishi \\ University for Business and Technology, namik.durmishi@ubt-uni.net \\ Ljubica Karakasova \\ Ss. Cyril and Methodius University \\ Frosina Babanovska-Milenkovska \\ Ss. Cyril and Methodius University \\ Renata Kongoli \\ Agricultural University of Tirana
}

Follow this and additional works at: https://knowledgecenter.ubt-uni.net/conference

Part of the Food Science Commons

\section{Recommended Citation}

Durmishi, Namik; Karakasova, Ljubica; Babanovska-Milenkovska, Frosina; and Kongoli, Renata, "Control some quality parameters of the natural juice of blueberry with different fruit content" (2017). UBT International Conference. 173.

https://knowledgecenter.ubt-uni.net/conference/2017/all-events/173

This Event is brought to you for free and open access by the Publication and Journals at UBT Knowledge Center. It has been accepted for inclusion in UBT International Conference by an authorized administrator of UBT Knowledge Center. For more information, please contact knowledge.center@ubt-uni.net. 


\title{
Control some quality parameters of the natural juice of blueberry with different fruit content
}

\author{
Namik Durmishi ${ }^{1}$, Ljubica Karakasova ${ }^{2}$, Frosina Babanovska-Milenkovska ${ }^{2}$, Renata \\ Kongoli $^{3}$ \\ 1Food Science and Biotechnology, University of business and technology, Pristina, \\ Kosovo \\ 2Faculty of Agricultural Sciences and Food, University of Ss. Cyril and Methodius, \\ R. Macedonia \\ 3 Faculty of Biotechnology and Food, Agricultural University of Tirana, Albania \\ namik.durmishi@ubt-uni.net
}

\begin{abstract}
During the study, were analyzed two natural juice with blueberry juice concentrate, packed in Tetra Pak. At the juice were studied these parameters: the technological process of juice production, the sensory characteristics (color, aroma, flavor and homogeneity), physical and chemical ( $\mathrm{pH}$ degree, refraction index, soluble solids degree ${ }^{\circ}$ Brix and turbidity expressed with NTU). The parameters were analyzed in the juice with fruit content of $50 \%$ and $25 \%$. From the sensoric aspect the most qualitative fluid resulted with a $50 \%$ fruit concentration, from the refractive index content and the degree of ${ }^{\circ}$ Brix higher results had $25 \%$ fruit juice concentrate, the $\mathrm{pH}$ rate was of approximate values while turbidity as a quality juice resulted liquid with fruit percentage $25 \%$. In conclusion we can conclude that the two fluids studied result within the norms for quality regulation, but the above-mentioned changes come from the fruit juice content.
\end{abstract}

Keywords: juice, blueberry, quality, sensory, $\mathrm{pH},{ }^{\circ} \mathrm{Brix}, \mathrm{NTU}$.

\section{INTRODUCTION}

Producing in particular the preservation of quality food products, in particular natural fruit juices, for human consumption is one of the most important humanitarian tasks for present and future generations. In this regard, fruits are an irreplaceable source of a large number of components of diverse composition for the proper nutrition of the human body. However, modernized to be the technology of preserving the fresh product, production losses are high. Therefore, processing these products and transforming them into final fruit-based natural fruit juices will impact on reducing losses and preserving products for a longer time. During the study, two products of the same Tetra Pak packaging product were analyzed, produced from the same raw material with blueberries, but with different fruit concentrations. Following the technological process and quality control were carried out, the liquid was produced in the market of the Polog region. The purpose of the study is: the application of the technological process for the production of natural cranberry juices with raw fruit raw materials, the control of quality parameters such as: sensory (color, aroma, flavor and homogeneity), quality control of physical and chemical $\mathrm{pH}$, index refractive, dry solids, the degree of ${ }^{\circ}$ Brix as well as the turbidity expressed by the NTU degree. The same quality parameters were analyzed and compared to blueberry juice with identical packaging but with different fruit percentages. The final goal of this paper is to familiarize the consumer with the quality characteristics of the natural blueberry juice, the comparison of the nutritional values in both fluids, and the release of the highest quality production. 


\section{MATERIALS AND METHODS}

The study was conducted at one of the fruit factories in the Polog region. From the beginning of the production process, the most modern techniques and technology for the production of Tetra Pak packing fruit juices have been applied. The samples were taken and analyzed at the plant during production, blueberry juice with different fruit concentrations. Different fruit concentrations of blueberry juices were studied and compared to qualitative sensory, physical and chemical parameters. Control during production is a very important factor, because through this action we monitor the fluid we produce, having in control that there is no deviation from normal fluid characteristics. As important elements during the control we have the $\mathrm{pH}$ measurement and the measurement of soluble solids, turbidity and sensory parameters. The sensory parameters were analyzed by the tasting method and the liquid evaluation was evaluated by 5 points for each point maximum of 20 . The refractive index and the degree ${ }^{\circ}$ Brix or dry soluble matter were measured with a digital instrument called refractometer. $\mathrm{PH}$ scale - measured with $\mathrm{pH}$-meter. Determination of turbidity with expressed turbidimeter with degree (NTU).

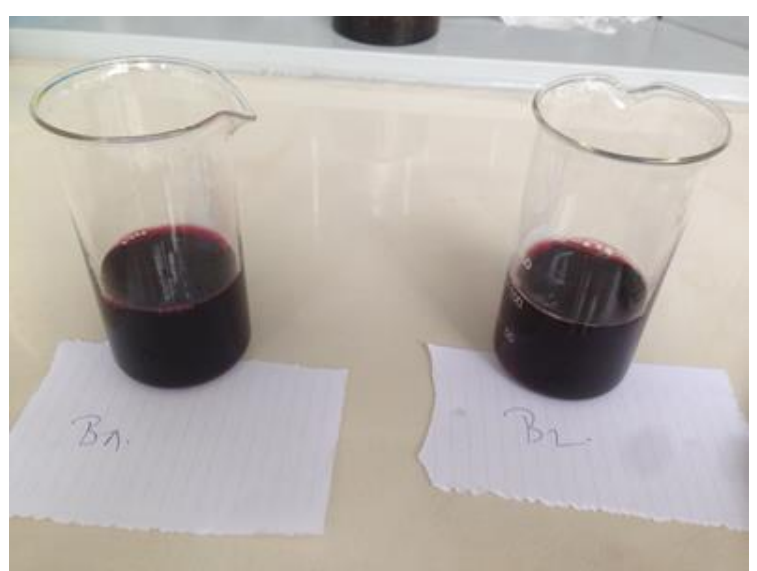

Fig.1. Qualitative evaluation of sensory parameters 


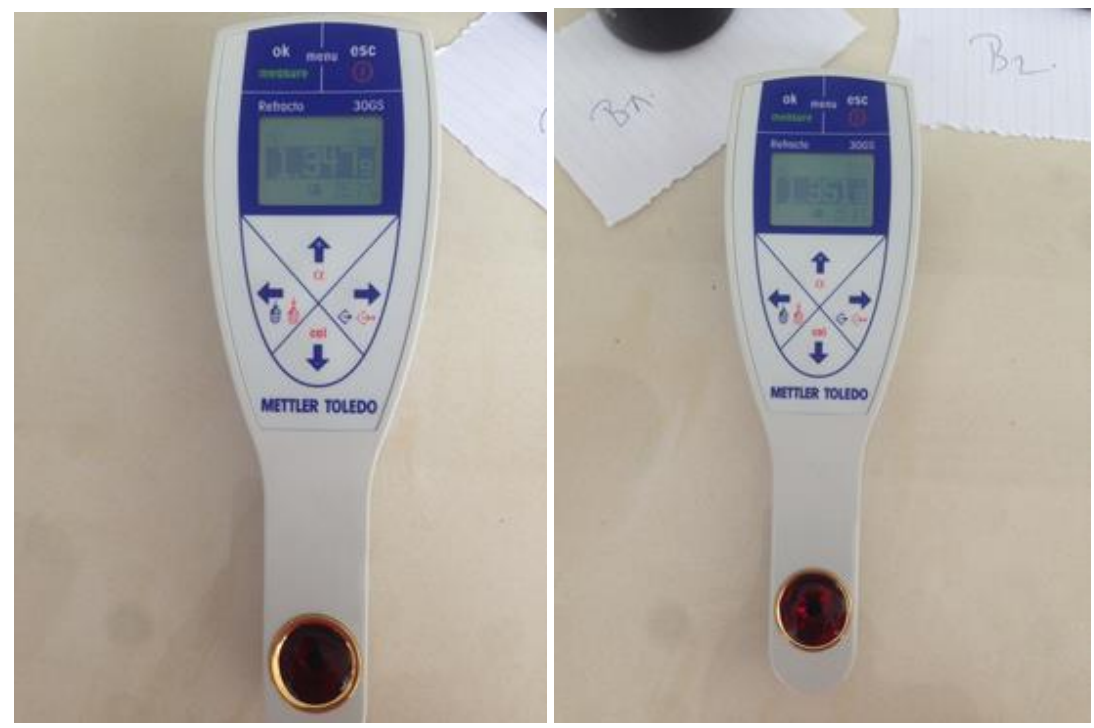

Fig. 2. Determination of refractive index and dry matter

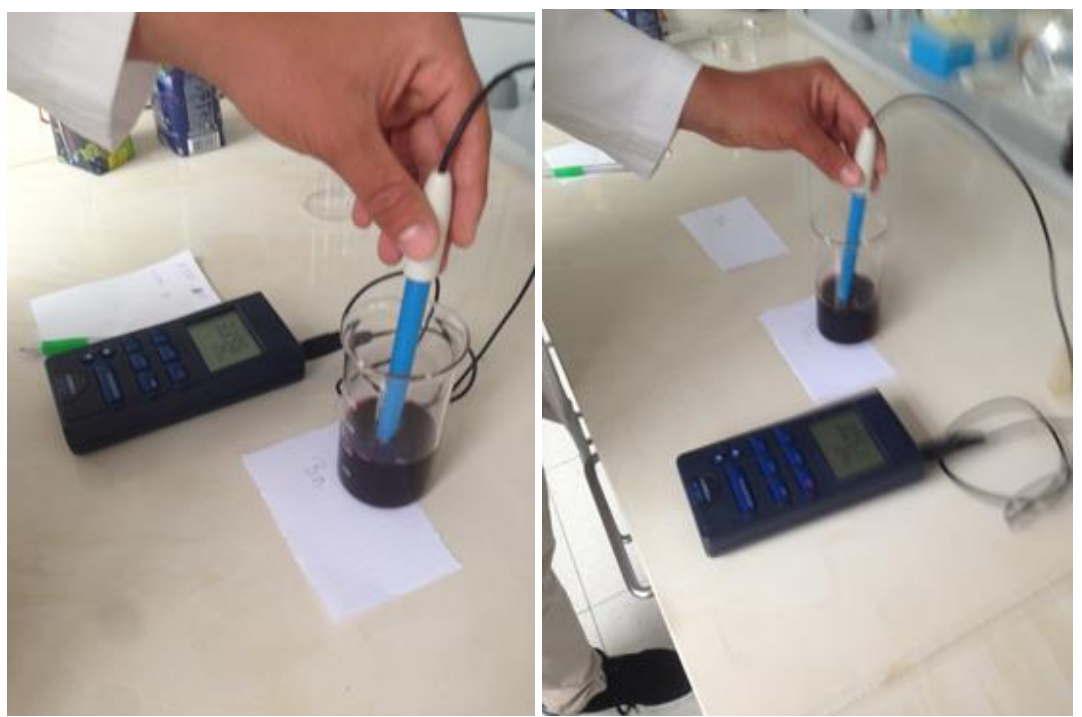

Fig.3. Determination of the $\mathrm{pH}$ scale 


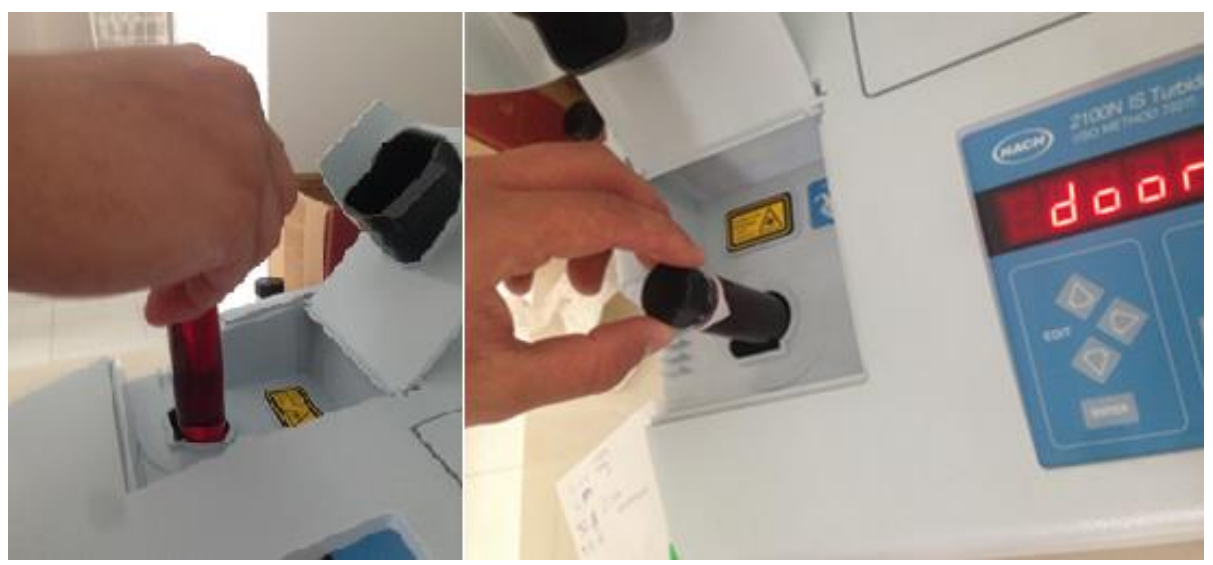

Fig. 5. Determination of turbidity (NTU)

\section{RESULTS AND DISCUSSION}

In graph 1 , the obtained results show that the juice that has been studied with $50 \% \mathrm{~B}_{2}$ fruit concentration has obtained from a total of 20 points, 5 per color, 5 aroma, 5 flavors and 4 homogeneities. The total score obtained by $\mathrm{B}_{1}$ juice is 17 , while the fluid with fruit concentration of $25 \% \mathrm{~B}_{2}$ is evaluated, color 5 points, 4 point aroma, 4 point flavor and 4 point juice $\mathrm{B}_{2}$ homogeneity is estimated at 19 points total. Based on the points obtained from the sensory aspect, juice $B_{2}$ results in higher quality. 


\section{Sensory parameters}

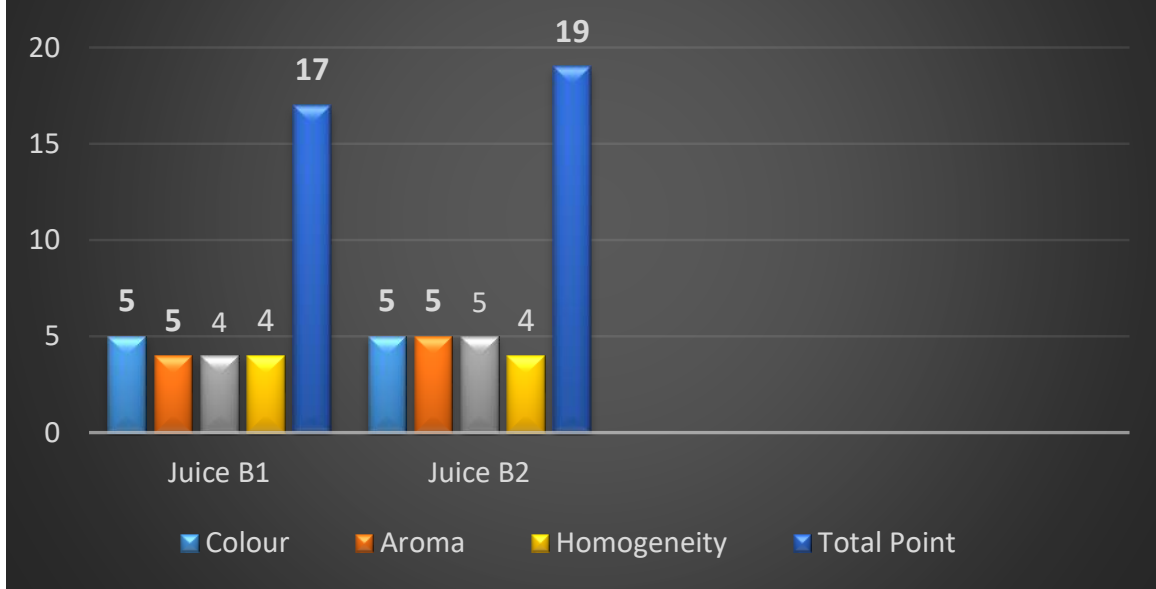

Graph. 1. Sensory parameters

The results obtained in the graph 2 show that the $\mathrm{B}_{1}$ fluid has a refractive index of $1.351 \mathrm{nD}$ and the degree ${ }^{\circ}$ Brix $=12.00$ and based on the results for the analyzed parameters this fluid is of higher quality compared to the $\mathrm{B}_{2}$ fluid which results in the lowest parameter is $1.347 \mathrm{nD}$ and ${ }^{\circ}$ Brix $=10.00$.

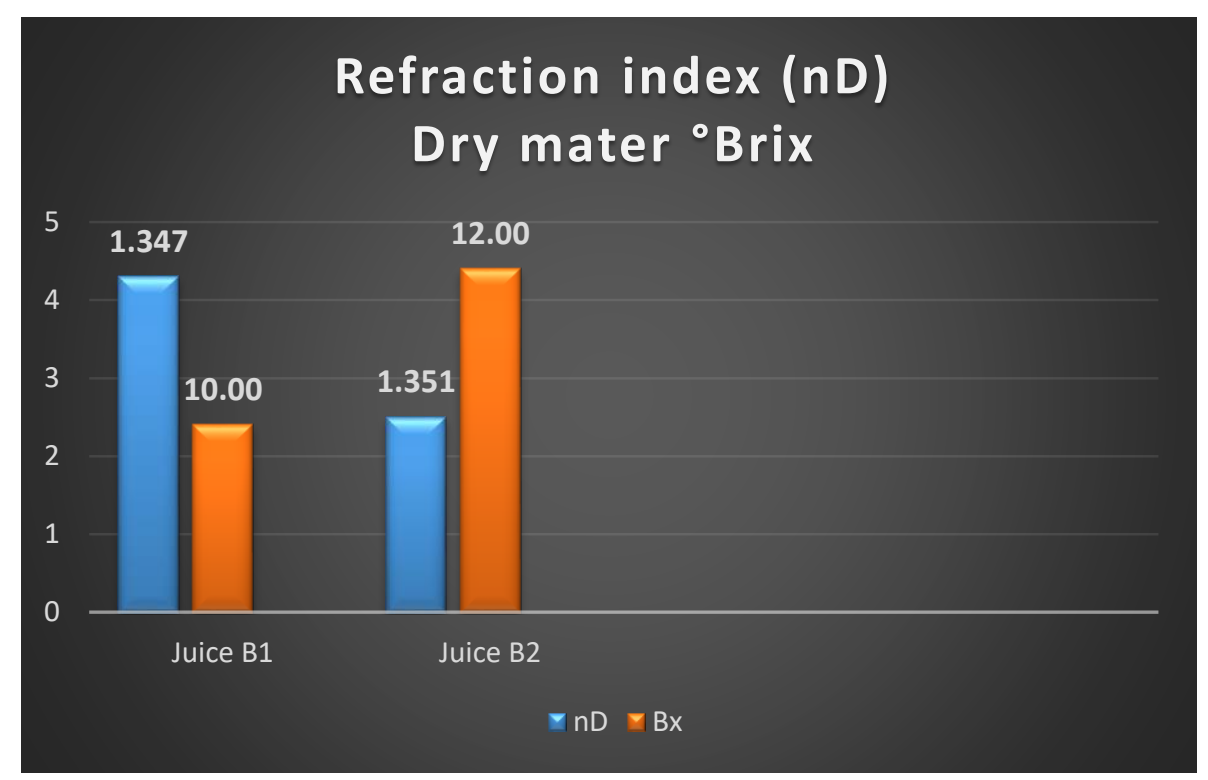

Graph. 2. Refraction index $(\mathrm{nD})$ and dry mater ${ }^{\circ}$ Brix 
The results obtained in graph 3 for the $\mathrm{pH}$ scale are within legal norms for quality, in both fluids studied $\mathrm{B}_{1}$ and $\mathrm{B}_{2}$ the results are approximate, the same resulted in sample $\mathrm{B}_{1} 3.38$ while in sample B2 3.05.

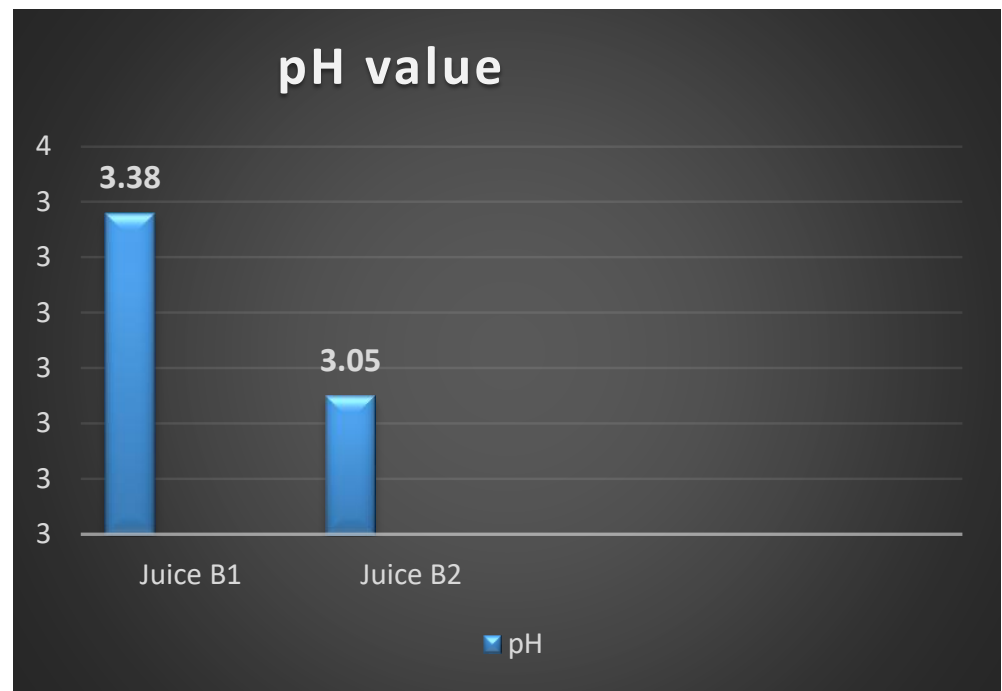

Graph. 3. $\mathrm{pH}$ value

The parameter studied in $\mathrm{B}_{1}$ fluid in the chart results 9.58 while in the $\mathrm{B}_{2}$ fluid the same results 4.69, from the results obtained for the turbidity parameter and NTU scales as the highest quality fluid result $\mathrm{B}_{1}$ fluid, high turbidity comes as a result of the highest percentage of juice fruits.

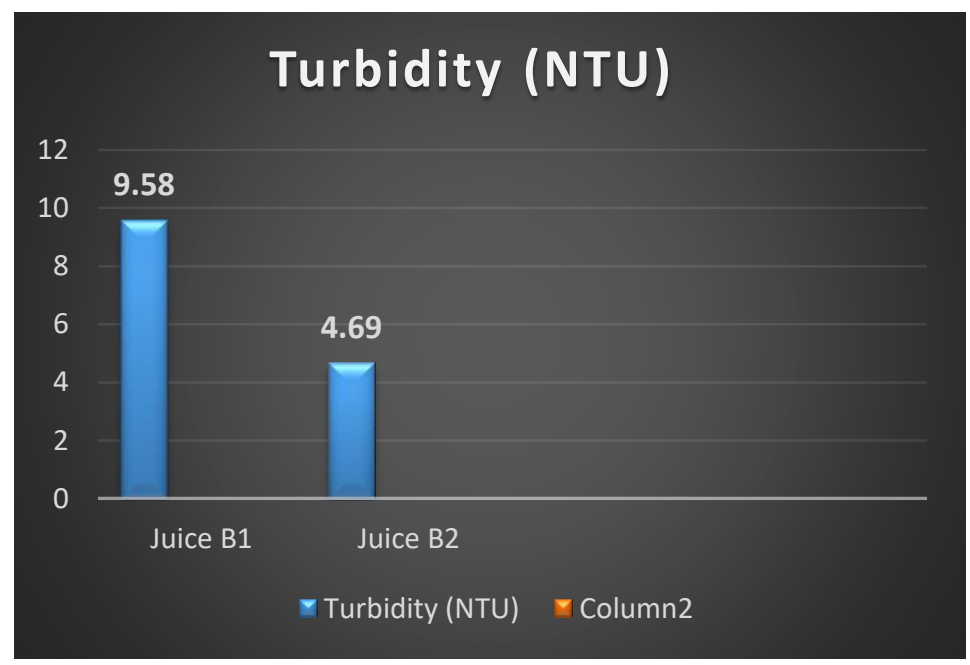

\section{CONCLUSION}

Graph. 4. Turbidity (NTU)

Based on the parameters analyzed and the results obtained we can conclude that: 
1. Juice $B_{1}$ and $B_{2}$ are natural juice based on the content of ingredients in the dry matter ", the same are high quality and acceptable juice, produced by contemporary standard techniques and technology;

2. The sensory parameters analyzed and the obtained results show that the highest quality fluid is the $\mathrm{B}_{2}$ sample from the points obtained 19 while the $\mathrm{B}_{1}$ fluid based on the sensory parameters is evaluated with a total of 17 points and the poorest quality;

3. The $\mathrm{pH}$ rate is within legal limits, the two types of juice resulted from 3.38 of $\mathrm{B}_{1}$ juice and 3.05 of juice $\mathrm{B}_{2}$;

4. The refractive index and the degree of ${ }^{\circ}$ Brix or the amount of dry soluble substance in the juice changes and as the higher quality juice is evaluated $\mathrm{B} 2$ because it has a degree of ${ }^{\circ} \mathrm{Brix} 12.00$ whereas the $\mathrm{B}_{1}$ juice has the lowest degree of degree ${ }^{\circ}$ Brix 10.00 .

5. The turbidity rate expressed in the NTU scale results in the boundary in sample B1 9.58 whereas in the $B_{2}$ sample results with lower margins of 4.69 because the same is in the statement of higher fruit content.

In conclusion we can conclude that the two fluids studied $\mathrm{B}_{1}$ and $\mathrm{B}_{2}$ result within the norms provided by law for quality, but the results show that there are differences in quality between them, this is based on the amount of juice fruit content

\section{REFERENCE}

1. Renata Kongoli, Iliriana Boci. "Përpunimi i frutave dhe perimeve".2013. Tiranë;

2. Eranda Mane. Ruajtja dhe ambalazhimi i produkteve ushqimore, 2011. Tiranë;

3. "Drejtimi i cilësisë në Indrustrinë Agroushqimore" nga Renata Kongoli;

4. Namik Durmishi. Teknologiia e prodhimit të pijeve jo-alkoolike dhe freskuese, 2017;

5. Postahrvest technology of fruits and vegetables. 2000, L.R. Verma and JK Josh;

6. Xhezair Idrizi, Namik Durmishi. Lëndët e para në industrinë ushqimore 1;

7. Gordana Niketic Aleksic.Tehnologija voca i povrca.1994. Beograd-Zemun;

8. Web faqe interneti,. 